\title{
Role of cytogenetic studies, protein electrophoresis and ISSR markers in assessment of genetic diversity in Stevia rebaudiana (Bertoni).
}

Shehab, Elham; Bekhit, M. M. M.; Abdel-Sabour, M. S.; El-aqaad, T. A. M. and El-Sheikh, A.A.

Corresponding author: makhlouf.bakhit@fagr.bu.edu.eg

\begin{abstract}
Chromosome number was investigated in a number of strains of Stevia rebaudiana. The chromosomes were analyzed during mitosis and different stages of meiosis. All stevia strains were found to had $2 \mathrm{n}=22$. The number of bivalents at diakinesis was 11 for all the studied strains. Analysis of SDS-PAGE of soluble protein revealed complete similarity (100\%) among the six strains of Stevia while two strains (broad and narrow leaves) are different in one band. Eight genotypes were assayed by inter-simple sequence repeat (ISSR) markers to differentiate and explore their genetic relationships. The level of polymorphism detected among the eight strains of stevia was $100.00 \%$ using inter simple sequence repeat (ISSR). A total of 231 clear bands were generated, out of which $34(14.72 \%)$ were unique bands. The total number of markers varied from 1 to 12 with a mean of 5.67 markers per primer.
\end{abstract}

Key words: chromosomes, Stevia, bivalents, SDS-PAG Eelectrophoresis, ISSR

\section{Introduction}

Stevia Cav. As a genus of (Eupatorieae, Asteraceae), the family include approximately 150200 species of herbaceous, shrub and sub-shrub plants (Gentry, 1996). Although geographically widespread, this genus occurs exclusively in tropical and subtropical regions of the United States and Central and South America (Robinson and King, 1977). Randi (1980) described the main uses of Stevia rebaudiana, which produces stevioside, a sweetener with no calories that does not ferment in the human body. Recently, many distinct strains of $S$. rebaudiana are currently being introduced, domesticated and assessed agronomically in Egypt. Although this species has not yet been extensively studied genetically, considerable genetic variability has been observed in plant size, flowering period, and stevioside content, which may vary from $2 \%$ to $10 \%$ (Magalhes, 2000)

Molecular markers such as RFLP, SSR, ISSR and AFLP, used to detect DNA polymorphism are used vastly for identification of artificial and natural hybrids in many plant species (Wolfe et al., 1998; Rajora and Rahman, 2003; Ruas et al., 2003; Shasany et al., 2005). Amongst the various DNAbased markers available, inter simple sequence repeat (ISSR) has been shown to give rapid, simple, reproducible and inexpensive means in molecular taxonomy, conservation, breeding and genetic diversity analysis. ISSR markers amplify regions between adjacent and inversely oriented microsatellites using di-, tri-, tetraand pentanucleotide SSR primers with the advantage that the information of the target DNA sequence is not required. The amplification depends on the variation, motif, frequency of SSRs that changed due to natural crossing and/or mutation induction (Carvalho et al., 2008). Thus, ISSR is excellent for fingerprinting and characterization of species and inter-specific hybrids (Carvalho et al., 2008; Kumar et al., 2008).
The main objective of this study was to determine the chromosome numbers of the strains of $S$. rebaudiana cultivated at EGYPT in order to obtain information that could be useful in breeding programs. The abnormality in the different stages of meiosis was mainly used to estimate the regularity of meiosis. It aimed also to assess the genetic fidelity through molecular markers analyses, which is important for promising newly introduced non caloric sweetener plant in Egypt. In the present study, we investigated the utility of ISSR markers in genetic diversity study of Stevia genotypes.

\section{Material and Methods}

The plant material (floral buds and roots) for the cytogenetic studies was collected from eight strains of $S$. rebaudiana cultivated at private farm and sugar crops research institute, Agriculture research Centre, Giza. Six of these strains were obtained kindly from Dr Ahmed Elsheikh, sugar crops research institute (Table 1).

\section{Mitotic and meiotic studies}

For the mitotic studies, root tips were obtained from from dark achenes germinated in gerbox, at room temperature. The root tips were pretreated with $\alpha$ promonaphthaline for $4 \mathrm{~h}$ at room temperature and fixed in ethanol-acetic acid $(3: 1, \mathrm{v} / \mathrm{v})$. Cytological preparations were obtained using the aceto-carmine technique (Eid, 1958). For meiotic analysis, floral buds were fixed in ethanol-acetic acid $(3: 1, \mathrm{v} / \mathrm{v})$ for approximately $24 \mathrm{~h}$ and the anthers then squashed onto slides in aceto-carmine (Eid, 1963).

The cytological preparations were examined by light microscopy. All cells in which it was possible to determine the chromosome number, the meiotic behavior and morphological features, were included in the analysis. Chromosome numbers were based on counts from an average of 25 cells per strain. 


\section{Molecular Marker}

Extraction of Total Protein: Bulked leaf sample (0.25) $\mathrm{g}$ of each sample was ground with liquid nitrogen and mixed with extraction buffer ( $\mathrm{pH} 7.5,50$ $\mathrm{mM}$ tris, 5\% glycerol and $14 \mathrm{mMB}$-mercaptoethanol) in a mortar with pestle, left overnight then vortexed for $15 \mathrm{sec}$ and centrifuged at $10.000 \mathrm{rpm}$ at $4^{\circ} \mathrm{C}$ for 10 min. The supernatants were transferred to new eppendorf tubes and kept at $20^{\circ} \mathrm{C}$ until used for electrophoresis analysis according to Laemmli (1970).

DNA Extraction: Genomic DNA was extracted from fresh young leaves of ten plants chosen randomly for each population by CTAB method of Doyle and Doyle (1987).

ISSR for DNA Amplification: ISSR-PCR reactions were conducted using 6 specific primers, for eight samples of stevia. ISSR analysis was performed with six primers procured from 1st Base Laboratories (Table 3). PCR reaction was performed in final volume of $50 \mu \mathrm{l}$ containing 1X Mytaq PCR Master Mix (Bioline, UK), $2 \mu \mathrm{M} /$ reaction of ISSR primer and 250ng of template DNA. The PCR was performed in Eppendorf Mastercycler ${ }^{\circledR}$ thermocyler. The PCR programme comprised of 40 cycles and the PCR tubes were subjected to the thermal profile given in Table 2. Following amplification, the PCR products were loaded on $1.2 \%$ agarose gel (HydraGene ${ }^{\mathrm{TM}}$ molecular grade), which was prepared in $1 \mathrm{X}$ TAE buffer containing $1.5 \mu \mathrm{g} / \mathrm{ml}$ o the Ethidium Bromide. The amplified products were electrophoresed for 1 hour at $100 \mathrm{~V}$. After separation, the gel was viewed under UV trans-illuminator.

These ISSR markers were converted into a matrix of binary data, where the presence of the band corresponded to the value of 1 and the absence to value 0 . The scores ( 0 or 1$)$ for each band were entered in the form of a rectangular data matrix (qualitative data matrix). The pair-wise association coefficients were calculated from qualitative data matrix using Jaccard's similarity coefficient (Jaccard, 1908). Cluster analysis for the genetic distance was then carried out using UPGMA (Unweighted Pair Group Method with Arithmettic Mean) clustering method. The genetic distances obtained from cluster analysis through UPGMA were used to construct the dendogram, depicting the relationships of the accessions using computer program NTSYS pc version 2.1 (Rohlf, 2000).

\section{Results and Discussion}

Almost all of the $S$. rebaudiana strains studied had 2 n $=22$, (Figure 1). Diakinesis was the only phase analyzed in prophase 1 in meiosis. Pairing was $n=11$ bivalents for all strains of $S$. rebaudiana, (Figure 2).

In the present study, an attempt was carried out to investigate the cytological behavior and chromosome number in meiotic and mitotic division of Stevia. Cytological examination revealed that the meiotic division of Stevia rebaudiana Bertoni was found to be normal. Therefore, the different stages of meiosis and mitosis were shown and given in Figures 1 and 2, respectively. From Figure (1) of meiotic examination, stages of pollen mother cells one can be concluded that the normal stages of diakinasis in prophase 1 of pollen mother cells in Figure A with eleven (11) bivalents (22 chromosomes) and one nucleolus and metaphase 1 in Figure B . Normal anaphase 1 stage showing in Figure C. In Figure-D Telophase stage in pollen mother cells of meiosis and showing in photograph-E, the normal quartet stage of Stevia rebaudiana. The basic number of chromosomes in Stevia seems to be $X=11$. Therefore to classify this point, further investigations are needed to determine the basic chromosomal clarify number in Stevia genotypes.

On the other hand, the cytological examinations of mitotic division stages were given in Figure (2). From this Figure, showing root tip cells and the tappetum layer of pollen mother cells with high mitotic activity. Telophase stage in Tappetum layer showing in Figure (2). These stages of mitotic division observed in the mitotic layers of the anthers, while the other observations were in root tip cells. From the previous results of the meiotic and mitotic examinations were discussed by many authors. The previous results of mitotic examination was in agreement with many authors as, Miyagawa et al., (1986) in cells of shoot primordial, Ferreira et al., (1988) in regenerated plants, Ferreira and Handro (1988) in calli cultures, Handro et al., (1993) in cell suspension of calli, Frederico et al., (1996) in root tip metaphase, Heta et al., (2001) in root tip cells with flow cytometry analyses and Vanessa et al., (2004) in mitotic cells of root tips. All reported the chromosome number of Stevia rebaudiana was $2 \mathrm{n}=22$ chromosomes, with a basic chromosome number $\mathrm{x}=\mathrm{n}=11$. On the other hand, Watanabe et al., (2001) reported that the chromosome number was $2 \mathrm{n}=24$ with haploid number $\mathrm{n}=12$ chromosomes. While Miyagawa et al., (1986) resulted from callus of the some Stevia plants, the $10.3 \%$ of observation cell shad the chromosome number $2 \mathrm{n}=22$ chromosomes. Therefore, the mitotic examination of the Stevia rebaudiana was clarified and strictly, while the meiotic observations which discovered few authers, Nakajima and Monteiro (1995) and Vanessa et al., (2004). The results of Nakajima and Monteiro (1995) which investigated several morphological types of Stevia pollen grain which related to cytological races or to breeding systems. Moreover, Vanessa et al., (2004) examined the chromosome number and some morphological feature of Stevia rebaudiana strains. The chromosomes were analyzed during the diakinasis stage of meiosis and their tetrad normality was discussed. The genus Stevia shows stability in chromosome number. Although most reports indicate 
that $\mathrm{n}=11(2 \mathrm{n}=22)$, (Darlington and Wylie, 1955; Bolkhoviskikh et al., 1969; Moore, 1973, 1974, 1977; Goldblatt, 1981, 1984, 1985, 1988; Goldblatt and Johnson, 1990, 1991, 1996, 1998). Galiano (1987) considered Stevia as a multibasic genus, with $\mathrm{x}$ $=11, \mathrm{x}=12$ and $\mathrm{x}=17$, while Frederico et al.(1996) considered its basic chromosome number as $\mathrm{x}=11$.

For $S$. rebaudiana, the chromosome number of $2 \mathrm{n}$ $=22(\mathrm{n}=11)$ previously reported by Frederico et al.
(1996) and Monteiro (1980, 1982) was confirmed here for various strains.

High rates of tetrad normality were also observed in the diploid strains. Because of irregularities which produce unbalanced gametes during meiosis, polyploids with an odd number of chromosome sets have a high level of sterility (Lawrence, 1980).

Figure (1): Showing in Pachytene stage of meiosis the 11 bivalents of Stevia (Stevia rebaudiana) pollen mother cells, B revealed metaphase $1, \mathrm{C}$ revealed anaphase 1 and D show metaphase 2, anaphase 2, $\mathrm{d}$ tetrad and pollen shape.

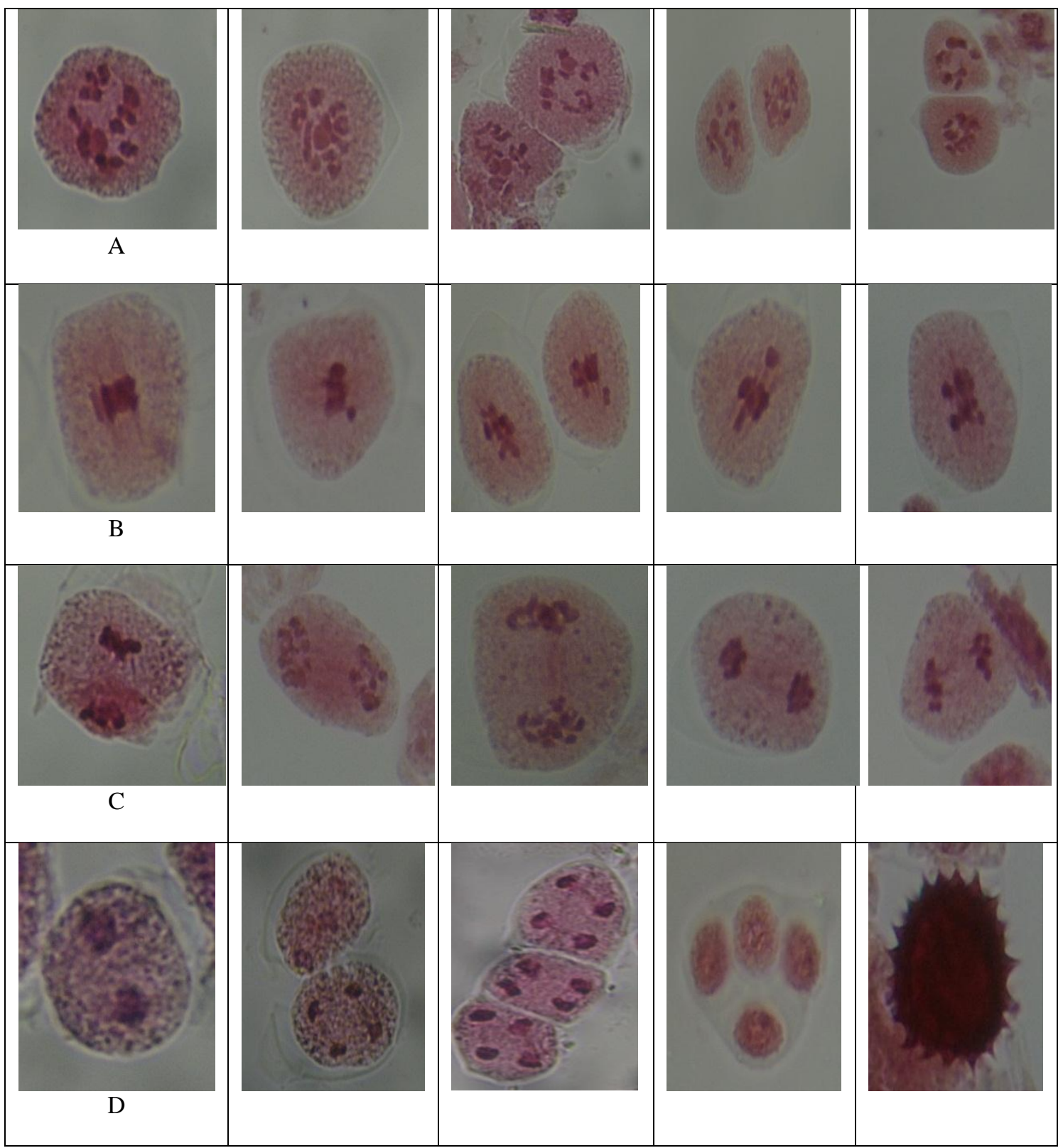

Figure (2): revealed the mitotic division stages; in cells of root tips with high mitotic activity in (poler view of metaphase) A and (side view of metaphase) B, while in C showing mitotic anaphase and D showing the Telophase stage in cells of root tips of Stevia. 


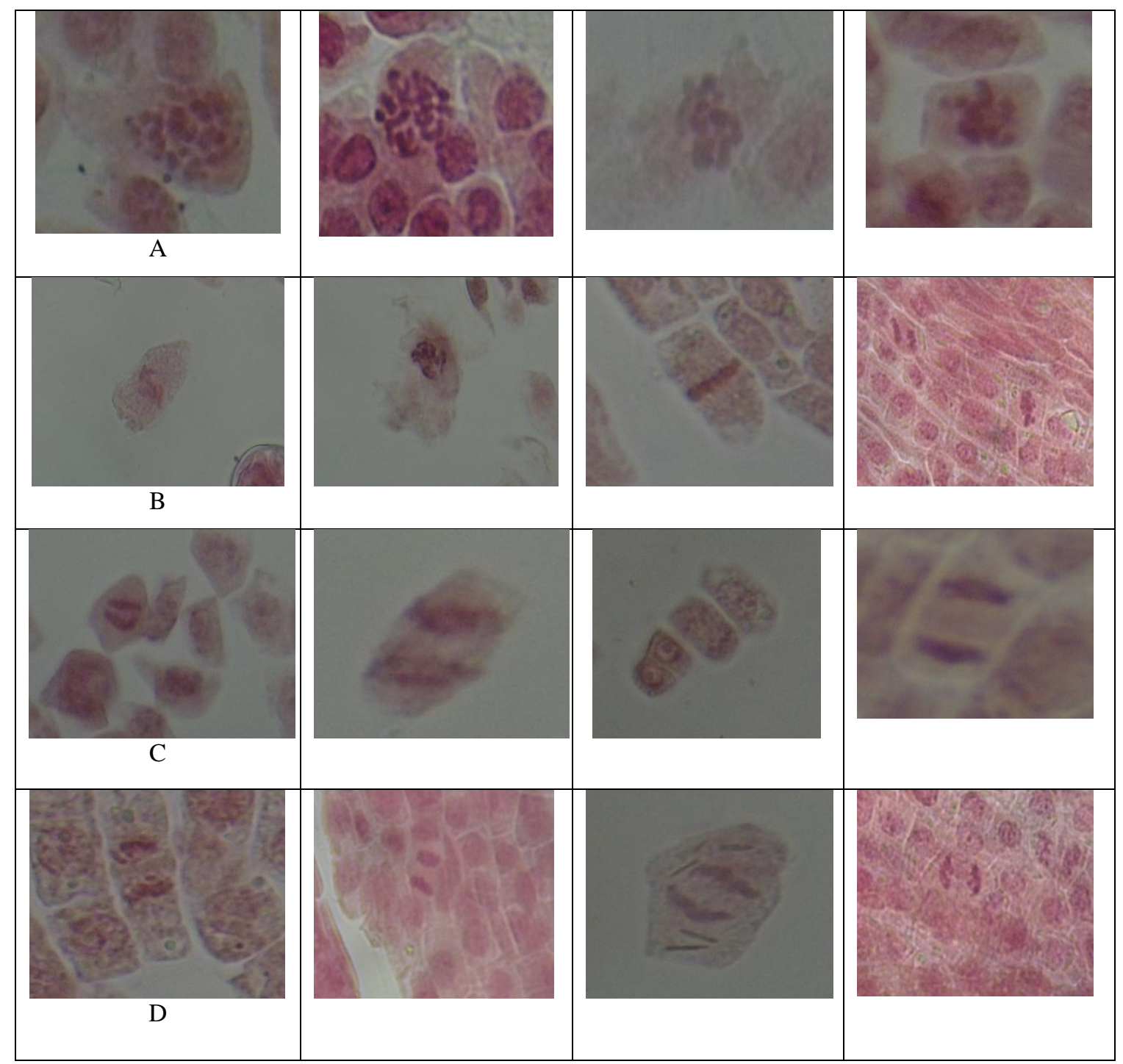

\section{Molecular Markers}

SDS-PAGE: Data presented in Fig. 3 and Table 1 summarized the SDS-PAGE of soluble proteins for the eight strains of Stevia. Analysis of gel revealed that molecular weight of protein sub units ranged between 11.99 to $72.00 \mathrm{kDa}$. Four bands at molecular weight of 72, 61, 47 and were obtained.

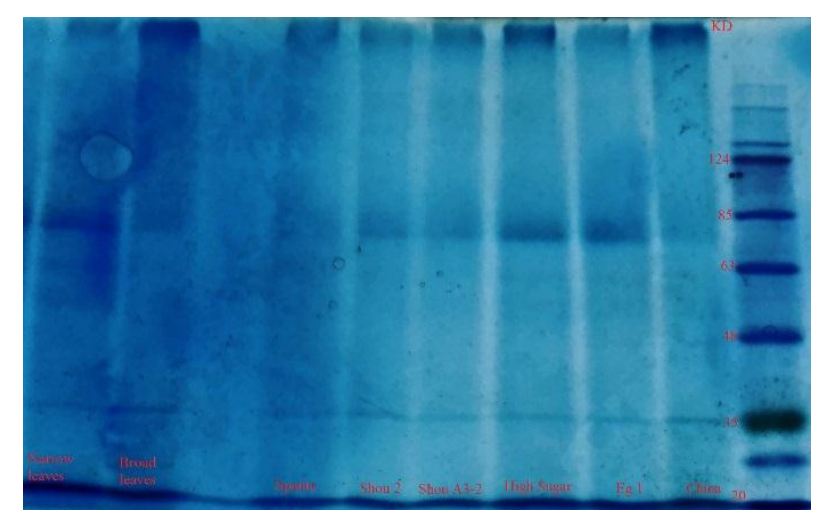

Fig. (3): SDS-PAGE profiles of soluble proteins extracted from Eight strains of stevia. 
Table 1. SDS-PAGE patterns of soluble proteins extracted from eight Stevia strains.

\begin{tabular}{|c|c|c|c|c|c|c|c|}
\hline China & $\mathrm{Eg}$ & $\begin{array}{l}\text { Higl } \\
\text { suga }\end{array}$ & $\begin{array}{l}\text { Shou } \\
A 3-2\end{array}$ & Shou-2 & Spanta & $\begin{array}{l}\text { Broad } \\
\text { leaves }\end{array}$ & $\begin{array}{l}\text { Narrow } \\
\text { Leaves }\end{array}$ \\
\hline
\end{tabular}

\begin{tabular}{llllllll}
\hline China & 1 & & & & & & \\
\hline Eg 1 & 1 & 1 & & & & & \\
\hline High Sugar & 1 & 1 & 1 & & & & \\
\hline Shou A3-2 & 1 & 1 & 1 & 1 & & & \\
\hline Shou 2 & 1 & 1 & 1 & 1 & 1 & & \\
\hline Spanta & 1 & 1 & 1 & 1 & 1 & 1 & \\
\hline Broad leaves & 0.667 & 0.667 & 0.667 & 0.667 & 0.667 & 0.285 & 1 \\
\hline Narrow leaves & 0.667 & 0.667 & 0.667 & 0.667 & 0.667 & 0.085 & 0.128 \\
\hline
\end{tabular}

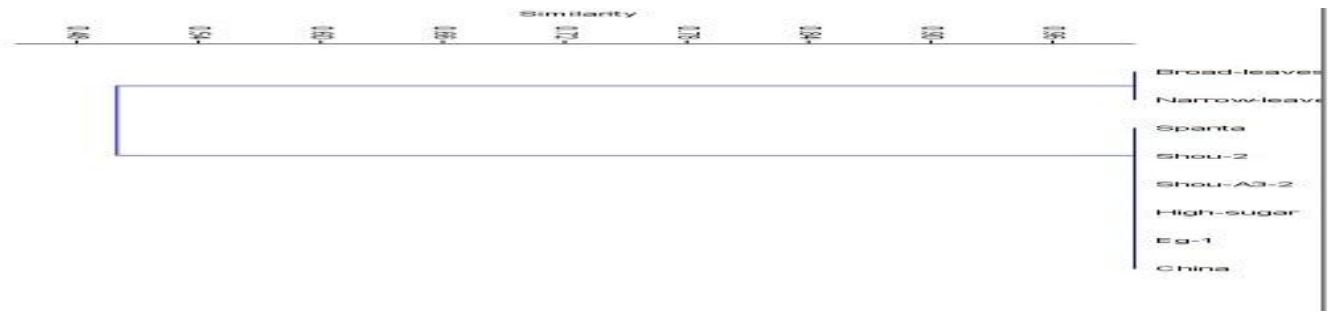

Fig. 4. Phylogenetic tree (Linkage dendrogram) of studied Stevia rebaudiana strains based on the analysis of Protein electrophoresis banding patterns.

Genetic similarity estimates based on SDS-PAGE banding patterns were calculated using method Jaccard's coefficient analysis (Table 1). The Jaccard's pairwise similarity coefficient values ranged from 0.085 (Narrow leaves and Spanta) to 1.00 (China, Eg1, High Sugar, Shou A3-2, Shou-2, and Spanta). The cluster constructed through NTSYS (2.1 pc) presented in the form of dendrogram are revealed in Figure 4. The cluster analysis revealed two main clusters. The first cluster consisted of six genotypes (China, Eg-1, High Sugar, Shou A3-2, Shou-2, and Spanta). Te second cluster consisted of two genotypes (Broad leaves and Narrow leaves).

Table 2. Thermocycling profile

\begin{tabular}{lcl}
\hline \multicolumn{1}{c}{ Cycle step } & Temperature $\mathrm{C}^{\circ}$ & Time $^{\circ}$ \\
\hline Initial Denaturation & 94 & 5 minutes \\
\hline Denaturation & 94 & 1 minute \\
\hline Annealing & $\mathrm{X}$ & 1 minute \\
\hline Extension & 72 & 1 minute \\
\hline Final extension & 72 & 10 minutes \\
\hline Hold & 4 & \\
\hline
\end{tabular}

Table 3. List of ISSR primers including nucleotide sequences, number of monomorphic and polymorphic bands, total bands and percentages of polymorphism for ISSR primers among eight Stevia strains

\begin{tabular}{|c|c|c|c|c|c|c|c|}
\hline No. & $\begin{array}{c}\text { ISSR } \\
\text { primers }\end{array}$ & Primer sequences & $\begin{array}{l}\text { Total } \\
\text { bands }\end{array}$ & $\begin{array}{c}\text { No. of } \\
\text { monomorphic } \\
\text { bands }\end{array}$ & $\begin{array}{c}\text { No. of } \\
\text { polymorphic } \\
\text { bands }\end{array}$ & $\begin{array}{l}\text { Unique } \\
\text { bands }\end{array}$ & $\begin{array}{c}\% \text { of } \\
\text { polymorphism }\end{array}$ \\
\hline 1 & ISSR- 1 & 5'-AGAGAGAGAGAGAGAGYC-3' & 64 & 0 & 64 & 9 & $100 \%$ \\
\hline 2 & ISSR- 2 & 5'-AGAGAGAGAGAGAGAGYG-3' & 52 & 0 & 52 & 5 & $100 \%$ \\
\hline 3 & ISSR- 3 & 5'-ACACACACACACACACYT-3' & 34 & 0 & 34 & 12 & $100 \%$ \\
\hline 4 & ISSR- 4 & 5'-ACACACACACACACACYG-3' & 37 & 0 & 37 & 3 & $100 \%$ \\
\hline 5 & ISSR- 5 & 5'-GTGTGTGTGTGTGTGTYG-3' & 16 & 0 & 16 & 1 & $100 \%$ \\
\hline \multirow[t]{2}{*}{6} & ISSR- 6 & 5'-CGCGATAGATAGATAGATA-3' & 28 & 0 & 28 & 4 & $100 \%$ \\
\hline & Total & & 231 & 0 & 231 & 34 & $100 \%$ \\
\hline
\end{tabular}


Table 4. Genetic distances, as the total number of ISSR band differences, among the studied Stevia rebaudiana strains after using six primers.

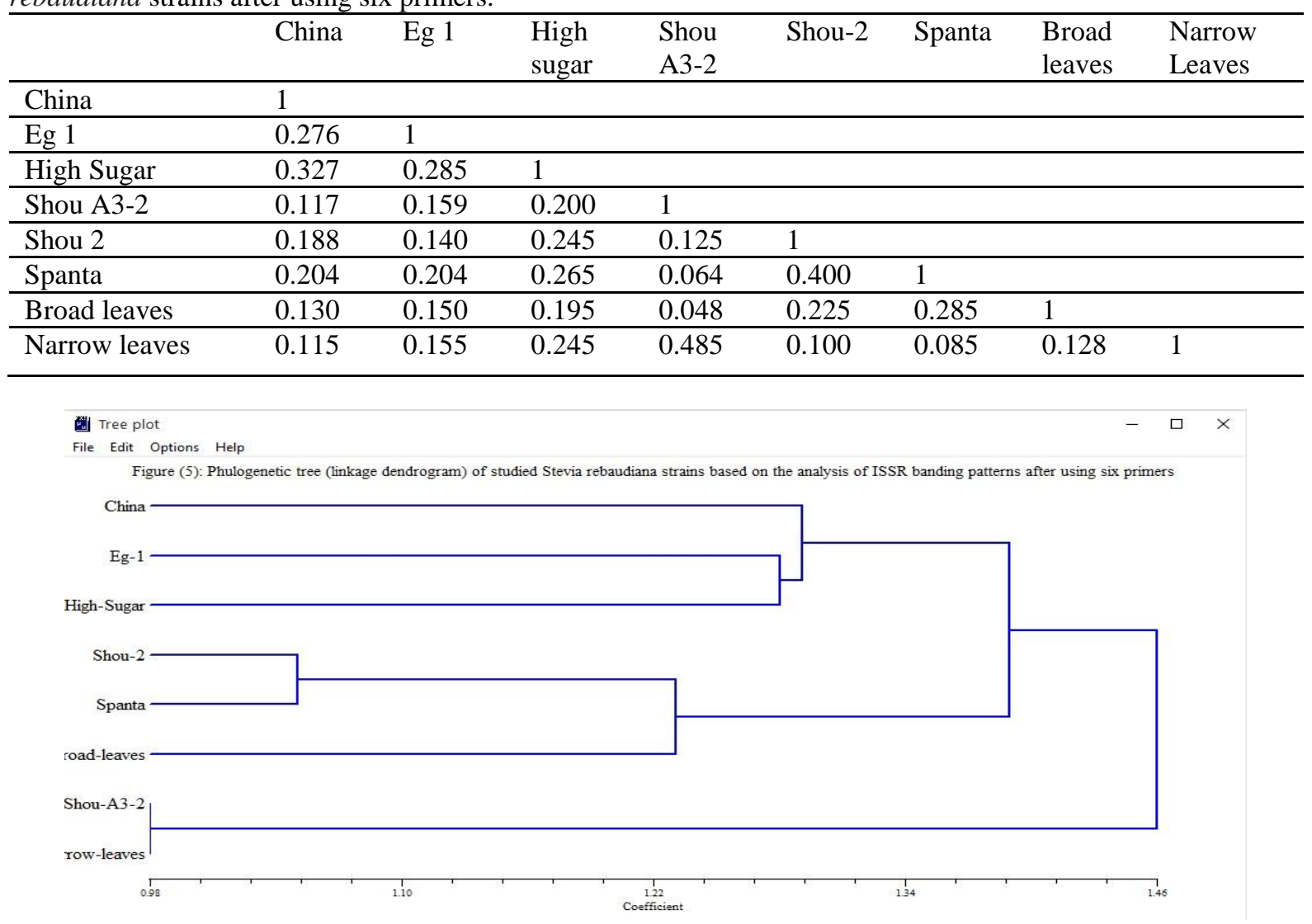

ISSR Analysis: Out of the 6 ISSR primers screened, positive banding patterns were obtained with all the used primers (Table 3). A total of 231 loci were amplified $(100.00 \%)$ were polymorphic and 34 were unique bands, $14.72 \%$ (Table 3 and Figure 6). The number of polymorphic markers for each primer ranged from 16 to 64 with a mean of 38.5 markers per primer. The highest polymorphic loci was obtained with primer ISSR 1 (64) and lowest was ISSR (5).

Genetic similarity estimates based on ISSR banding patterns were calculated using method Jaccard's coefficient analysis (Table 5). The Jaccard's pairwise similarity coefficient values ranged from 0.048 (Broad leaves and Shou A3-2) to 0.485 (Narrow leaves and Shou A3-2) with an average of 0.27, for a single primer based ISSR patterns. The cluster constructed through NTSYS $(2.1 \mathrm{pc})$ presented in the form of dendrogram are shown in Figure 5. The cluster analysis revealed two main clusters. The first cluster was further divided into two sub clusters. The first sub-cluster consisted of (Eg-1 and High Sugar beside China which found in a separate sub-cluster). The second Sub-cluster consisted of (Spanta and Shou 2 beside Broad leaves which located in a separate subcluster). The second cluster contained (Narrow leaves and Shou-A3 2). The six ISSR primers that were selected for analysis generated 231 ISSRs, with an average 38.5 products/primer. Cluster analysis indicated that the different genotypes studied had a great diversity between them according to their similarity coefficients. The acquired data in this investigation proved the significance of ISSR in the discrimination among the studied genotypes, which is in concordance with the results of Heikal et al.,(2008); Neha et al., (2016); Saini et al., (2004); Blair et al.,(1999); Lakshmi et al., (2002); Yadav et al., (2007). ISSR products are usually dominant markers and are inherited in simple Mendelian fashion, therefore verified as to be taxonomically and evolutionary useful (Demeke and Adams, 1994; Nkongolo et al., 2002). It was noticed that different primers gave different levels of polymorphism (Table $3)$. This can be explained on the presumption that homology of sequences of primers with the complementary sequences present in stevia genotypes genome. ISSR technique is a common and wellproven tool in genetic studies and a suitable system for detecting total genetic variation and it's partitioning within and among populations. This technique has been effectively used in a variety of taxonomic and genetic diversity studies (He et al., 2007 and Dos Santos et al., 2011. Stevia showed a high percentage of genetic differentiation. The level of genetic diversity detected by ISSR are in overall agreement with studies by Han et al., (2007). 


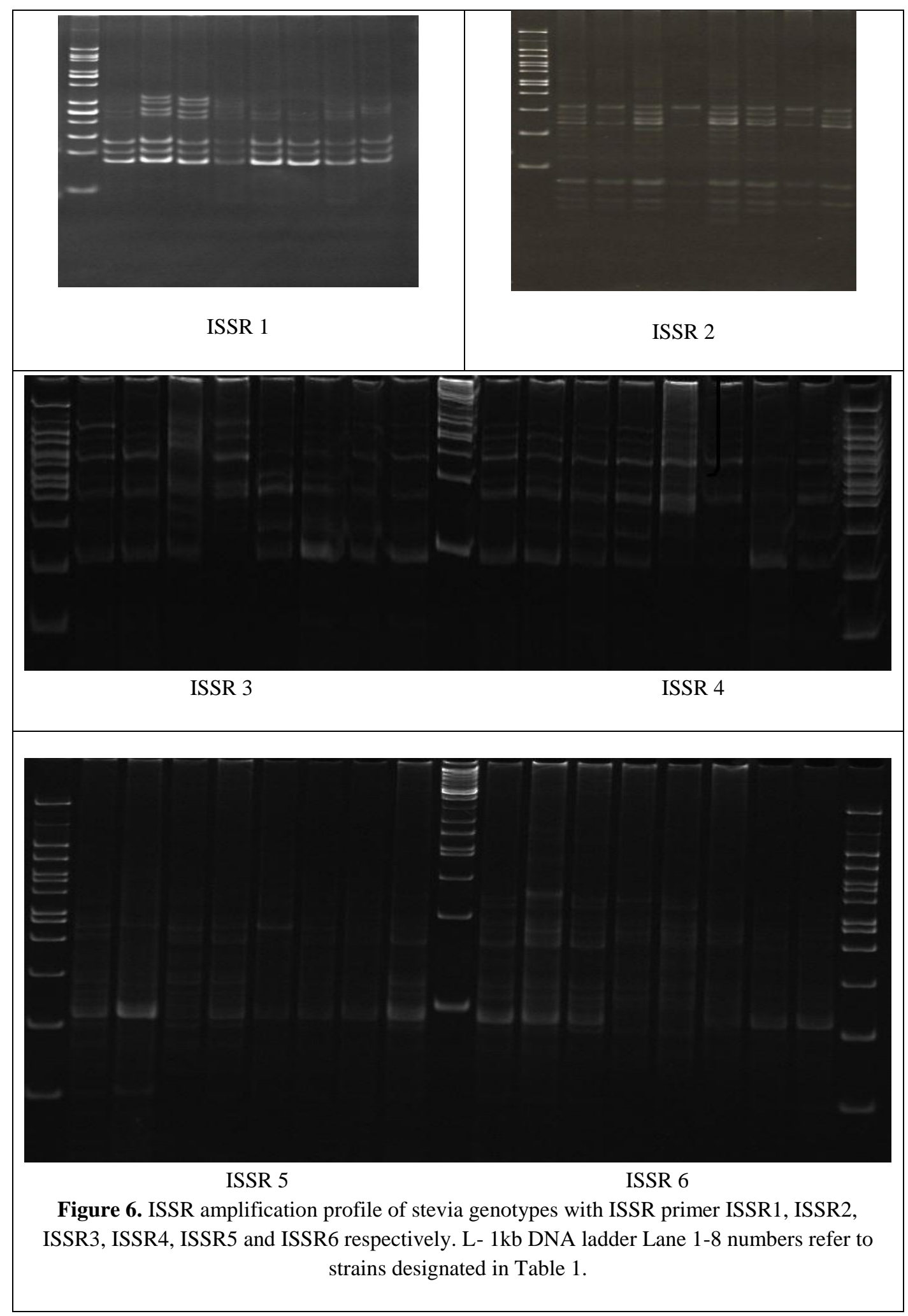

This result is in agreement with those reported by Chandrika and Ravishankar (2009), who employed ISSR markers to determine the genetic fidelity of Ochreinauclea missionis plantlets with twenty nine ISSR primers generated total of 183 clear, distinct and reproducible band of $2.73 \%$ polymorphism.

\section{CONCLUSION}

The present study showed that ISSR technique is quick and reliable which put ISSR as a preferred method for breeders in assessing the genetic diversity for utilization in breeding programmes. ISSR is 
excellent at detecting high level of genetic diversity and relationship in Stevia genotypes and therefore can be further established as an essential basis to help in stevia future conservation and breeding programmes. As a conclusion, the information gathered from this study is a valuable tool towards proper breeding strategies in producing stevia with high sweetener content in Egypt. The results obtained here open new possibilities for genetic breeding programs of $S$. rebaudiana in Egypt since the selection of plants for commercial production could possibly overcome the shortage of sugar cane production and increasing the level of stevioside compounds. Despite the male sterility present in various strains of $S$. rebaudiana, agamospermy (Monteiro, 1980) could ensure a sufficient seed yield to allow the genetic breeding of this species.

\section{References}

Blair, M. W., Panaud, O. and McCouch, S. R.(1999). Inter-simple sequence repeat (ISSR) amplification for analysis of microsatellite motif frequency and fingerprinting in rice (Oryza sativa L.). Theor Appl Genet, 98, 780-792.

Bolkhoviskikh $Z$, Grif $V$, Matvejeva $T$ and Zakharyeva HV (1969) Chromosome number of flowering plants. VL Komarov Botanical Institute, Academy of Sciences of the USSR,Moscou, 926 pp.

Carvalho A., Lima-Brito J., Maias B. and GuedesPinto H.(2008). Genetic diversity and variation among botanical varieties of old Portuguese wheat cultivars revealed by ISSR Assays. Biochem Genet., 47, 276-294.

Chandrika, M. and V. Ravishankar, 2009. Genetic fidelity in micropropagated plantlets of Ochreinauclea missionis an endemic, threatened and medicinal tree using ISSR markers African Journal of Biotechnology, 13: 2933-2938.

Darlington C and Wylie A P (1955) Chromosome Atlas of Flowering Plants. 2nd edition. George Allen and Unwin Ltd., London, 519 pp.

Demeke, P. and Adams, R. P. (1994). The use of RAPDs to determine germplasm collection strategies in the African species Phytolacca dodecantra (Phytholaccaceae). In Conservation of plant genes II:Utilisation of ancient and modern DNA (pp131-140). Missourri Botanical Garden, Missourri.

dos Santos, L. F., de Oliveira, E. J., dos Santos Silva, A., de Carvalho, F. M., Costa, J. L., and Pádua, J. G. (2011). ISSR markers as a tool for the assessment of genetic diversity in Passiflora. Biochemical Genetics, 49,(7-8),540-554.

Doyle, J. J. and J. L. Doyle, 1987. A rapid DNA isolation procedure for small quantities of fresh leaf tissue. Phytochem. Bull., 19: 11-15
Eid, S. E., (1958).Preservation of stainability of the chromosomes in material fixed in aceto alcohol. Egypt J. Bot., 1: 93-96.

Eid, S.E., (1963). A safe method for making squash preparations permanent. Alex. J. Agric. Res., 11: 213-215.

Ferreira, C. M. and Walter Handro(1988). Production, maintenance and Plant regeneration from cell suspension cultures of Stevia rebaudiana Bertoni. Plant Cell Reports 7: 123-126.

Ferreira, C. M., and W. Handro (1988). Stevia rebaudiana mature leaf culture, propagation, colchicines effect and Culture medium optimization. Planta Medica. 54: 2, 157-160.

Frederico A P, Ruas P M, Marin-Morales M A, Ruas $C \quad F$ and Nakajima $J \quad N \quad$ (1996) Chromosome studies in some Stevia Cav. (Compositae) species from southern Brazil. Rev Bras Genet 19:605-609.

Galiano NG (1987) Estudios cromosomicos en especies argetinas de Stevia (Compositae). Darwiniana 28:311-315.

Gentry AH (1996) A Field Guide of the Families and Genera of Woody Plants of Northwest South America (Colombia, Ecuador, Peru) with Supplementary Notes on Herbaceus Taxa. The University of Chicago Press, Chicago, 895 pp.

Goldblatt P (1981) Index to Plant Chromosome Numbers 1975-1978. Monographs in Systematic Botany from the Missouri Botanical Garden. v. 5. Missouri Botanical Garden, St.Louis, 553 pp.

Goldblatt P (1984) Index to Plant Chromosome Numbers 1979-1981. Monographs in Systematic Botany from the Missouri Botanical Garden. Vol. 8. Missouri Botanical Garden, St. Louis, 432 pp.

Goldblatt P (1985) Index to Plant Chromosome Numbers 1982-1983. Monographs in Systematic Botany from the Missouri Botanical Garden. v. 13. Missouri Botanical Garden, St. Louis, 224 pp.

Goldblatt P (1988) Index to Plant Chromosome Numbers 1984-1985. Monographs in Systematic Botany from the Missouri Chromosomes and morphology of $S$. rebaudiana cytotypes 221 Botanical Garden. v. 23. Missouri Botanical Garden, St.Louis, 264 pp.

Goldblatt P and Johnson DE (1990) Index to Plant Chromosome Numbers 1986-1987. Monographs in Systematic Botany from the Missouri Botanical Garden. v. 30. Missouri Botanical

Goldblatt P and Johnson DE (1991) Index to Plant Chromosome Numbers 1988-1989. Monographs in Systematic Botany Garden, St. Louis, 238 pp.

Goldblatt $P$ and Johnson DE (1996) Index to plant chromosome numbers 1992-1993. Monographs in Systematic Botany from the Missouri Botanical Garden. v. 58. Missouri Botanical Garden, St. Louis, $276 \mathrm{pp}$.

Goldblatt P and Johnson DE (1998) Index to Plant Chromosome Numbers 1994-1995. Monographs in Systematic Botany from the Missouri Botanical 
Garden. v. 69. Missouri Botanical Garden, St. Louis, $208 \mathrm{pp}$.

Han, Y. C., Teng. C. Z., Zhong, S., Zhou, M. Q., Hu, Z. L. and Song, Y. C. (2007). Genetic variation and clonal diversity in populations of Nelumbo nucifera (Nelumbonaceae) in central China detected by ISSR markers. Aquat Bot.,86,69-75.

Handro, W., C. M. Ferreira., and E. I. S. Floh (1993). Chromosomal variability and growth rate in cell suspension cultures of Stevia rebaudiana (Bert.). Plant. Sci. 93, 1-2, 169-176.

Hata S., T. Yomo., and S. Fujita (2001). Breeding of triploid plants of Stevia (Stevia rebaudiana Bertoni).with high rebaudioside A content. Japanese Journal of Tropical Agriculture. 45: 4, 281- 289., 26 ref.

He, F., Kang, D., Ren, Y., Qu, L. J., Zhen, Y., Gu, H. (2007).Genetic diversity of the natural populations of Arabidopsis thaliana in China. Heredity, 99,423-431.

Heikal, A., H., Badawy, O. M. and Afaf, M. H. (2008). Genetic Relationships among Some Stevia (Stevia Rebaudiana Bertoni) Accessions Based on ISSR Analysis. Research Journal of Cell and Molecular Biology, 2(1), 1-5.

Jaccard, P. (1908). Nouvelles recherches sur la distribution florale. Bull Soc Vaudoise C. Sci Nat., 44,223-270.

Kumar R. S., Parthiban K. T. and Rao M. G. (2008). Molecular characterization of Jatropha genetic resources through intersimple sequence repeat (ISSR) markers. Mol Biol Rep., 39, 1951 1956.

Laemmli, U.K.,1970. Cleavage of structural proteins during assembly of head bacteriophage T4. Nature, 227: 680-685.

Lakshmi, M., Parani, M., Rajalakshmi, S. and Parida, A. (2002). Analysis of species relationship among seven small millets using molecular markers. J Plant Biochem Biotechnol, 11(2), 85-91.

Lawrence W J C (1980) Melhoramento Genético Vegetal. v. 6. EDUSP, S户o Paulo, 75 pp.

Magalhes PM (2000) Agrotecnologa para el cultivo de estévia o hierba dulce. In: Fundamentos de Agrotecnologa de Cultivo de Plantas Medicinales Iberoamericanas. CYTED-CAB, Bogot, pp 441450.

Miyagawa, H., N. Fujioka., H. Kohda., K. Yamasaki., k. Taniguch., and R. Tanaka (1986). Studies on the tissue culture of Stevia Rebaudiana and its components. ( $\Pi$ ). Induction of shoot primordial. Planta Medica. 4: 321-323.

Monteiro R (1980) Taxonomia e biologia da reproduçəo de Stevia rebaudiana Bert. Masters Thesis, Universidade Estadual de Campinas, Campinas.
Monteiro R (1982) Estudos cromossômicos em Stevia rebaudiana-Série Multiaristatae no Brasil. Rev Bras Bot 5:5-15.

Moore R J (ed) (1974) Index to Plant Chromosome Numbers 1972. Regnum Veg 91:1-108.

Moore R J (ed) (1977) Index to Plant Chromosome Numbers 1973-1974. Regnum Veg 96:1-257.

Moore R J (ed) 1973. Index to Plant Chromosome Numbers 1967-1971. Regnum Veg 90:1-539.

Nakajima, J. N., and R. Monteiro (1995).Uniformity of pollen grains in 18 Brazilian species of Stevia Cav. (Eupatorieae,Asteraceae). Natuealia. 20: 9 -19.

Neha, S., Rajinder, K. And Vaidya, E. (2016). Potential of RAPD and ISSR marker or assessing genetic diversity among Stevia rebaudiana Bertoni accessions. Indian J. Of Biotech., 15, 95100.

Nkongolo, K. K., Michael, P. and Gratton, W. S. (2002).Identification and characterization of RAPD markers inferring genetic relationships among Pine species. Genome, 45, 51-58.

Rajora, O.P. and Rahman, M.H. (2003). Microsatellite DNA and RAPD fingerprinting, identification and genetic relationships of hybrid poplar (Populus x canadensis) cultivars. Theor. Appl. Genet., 106, 470-477.

Randi AM (1980) Germinaç^o de Stevia rebaudiana Bert. Masters Thesis, Universidade Estadual de Campinas, Campinas.

rebaudiana Bertoni. Plant Cell Reports 7: 123-126.

Robinson H and King RM (1977) Eupatoriaesystematic review. In: Heywood VH, Harbone JB and Turner BL (eds) The Biology and Chemistry of the Compositae. V 1. Academic Press Inc., London, pp 286-437.

Rohlf, F. J. (2000). NTSYS-pc Numerical Taxonomy and Multivariate Analysis System version 2.1. Owner manual.

Ruas, P. M., Ruas, C. F., Rampim, L. and Carvalho, V. P. (2003). Genetic relationship in Coffea species and parentage determination of interspecific hybrids using ISSR (Inter-Simple Sequence Repeat) markers. Genet. Mol. Biol., 26, 319-327.

Saini, N., Jain, N., Jain, S. and Jain, R. K. (2004). Assessment of genetic diversity within and among Basmati and non-Basmati rice varieties using AFLP, ISSR and SSR markers. Euphytica, 140 , 133-146.

Shasany, A. K., Darokar, M. P., Dhawan S., Gupta, A. K. (2005). Use of RAPD and AFLP markers to identify inter- and intraspecific hybrids of Mentha. J. Hered., 96, 542-549.

Vanessa M. de Oliveira., ElianaR. ForniMartins., Pedro M. Magalhães., and Marcos N. Alves (2004).Chromosomal and morphological studies of diploid and polyploidcytotypes of Stevia rebaudiana Bertoni (Eupatorieae, Asteraceae) Genet.Mol. Biol.vol.27. 
Yadav, S., Jain, S., Jain, V., Jain, R.K. (2007). Genetic analysis of CMS, restorer, hybrid and open-pollinated genotypes of Indian pearl millet (Pennisetum glaucum (L.) R. Br.) using ISSR markers. Indian J. Biotechnol., 6,340-348.

Watanabe, K., T. Yahara., A. Soejima., and M. Ito (2001). Mexican species of the genus Stevia (Eupatorieae, Asteraceae) chromosome numbers and geographical distribution. Plant Species Biology 16 (1) 49-68.

Wolfe, A. D., Xiang, Q. Y. and Kephart, S. R. (1998). Assessing hybridization in natural populat ions of Penstemon (Scrophulariaceae) using hypervariable intersimple sequence repeat (ISSR) bands. Mol. Ecol., 7, 1107-1125. 